\title{
The rs361525 polymorphism does not increase production of tumor necrosis factor alpha by monocytes from alpha-1 antitrypsin deficient subjects with chronic obstructive pulmonary disease - a pilot study
}

Jennie M. Gane ${ }^{1,3^{*}}$, Robert A. Stockley ${ }^{2}$ and Elizabeth Sapey ${ }^{1}$

\begin{abstract}
Background: Polymorphisms in the TNF-A gene have been associated with chronic obstructive pulmonary disease (COPD) in some case-control studies. Previous work has shown that COPD/chronic bronchitis subjects with alpha-1 antitrypsin deficiency with the rs361525 TNF-a single nucleotide polymorphism have 100 times more TNF-in spontaneous sputum than disease matched controls. Our objective was to determine if the presence of this polymorphism increased TNF-a production by blood monocytes from COPD subjects.

Findings: Monocytes from 18 COPD/alpha-1 antitrypsin deficient subjects, with and without the rs361525 polymorphism, were cultured in the presence or absence of lipopolysaccharide. Cell-free supernatants were analyzed by ELISA and real-time PCR performed using CDNA from extracted RNA. Baseline expression of TNF-a messenger RNA was no different between the groups. No difference in messenger RNA or secreted protein was observed over time in un-stimulated cells. TNF-a messenger RNA expression and protein was not higher in lipopolysaccharide-stimulated monocytes from subjects with the polymorphism compared to cells from patients with the wild-type allele.

Conclusions: This small pilot study did not provide an explanation for the findings of earlier observations of the association of the rs361525 polymorphism with TNF-a in airways secretions. Possible reasons for the lack of concordance include the study of blood rather than tissue cells, the use of a single stimulant rather than biological secretions and the need for far greater subject numbers to overcome intra-subject variation in monocyte TNF-a production.
\end{abstract}

Keywords: TNF-a, COPD, Monocytes, Polymorphism, Alpha-1 Antitrypsin Deficiency

\footnotetext{
* Correspondence: jenniegane@doctors.org.uk

${ }^{1}$ Institute of Inflammation and Ageing, University of Birmingham, Edgbaston, Birmingham B15 2TT, UK

${ }^{3}$ Centre for Translational Inflammation Research, New Queen Elizabeth Hospital, University of Birmingham Laboratories, Institute of Inflammation and Ageing, Edgbaston, Birmingham B15 2TT, UK

Full list of author information is available at the end of the article
} 


\section{Findings}

Introduction

Chronic obstructive pulmonary disease (COPD) is a debilitating disease most commonly caused by smoking. However, only $25 \%$ of smokers develop COPD, suggesting other contributing factors, such as genetic susceptibility [1]. The only well described example of genotype influencing the development of COPD is Alpha-1 Antitrypsin Deficiency (AATD), characterised by deletions/substitutions within the serpinA1 gene. The resultant reduction of neutrophil elastase-buffering alpha-1 antitrypsin leads to the development of airflow obstruction and emphysema [2].

There is a pressing need to identify new therapeutic targets in COPD, to modify disease and improve outcomes. COPD is heterogeneous and it is possible that there are many potential targets, each affecting a subset of patients. One such target may be tumor necrosis factor-alpha (TNF- $\alpha$ ) which has been implicated in the pathogenesis of COPD in animal studies [3, 4] and observational human studies [5]. Whilst TNF- $\alpha$ is not ubiquitously raised in COPD [6] and anti-TNF- $\alpha$ treatments are not efficacious in a generalised COPD population [7], single nucleotide polymorphisms (SNPs) in the TNF-A gene have been identified that might enhance susceptibility to COPD by increasing inflammatory output. Wood et al characterised a cohort of 424 unrelated patients with COPD and AATD and determined that the rs361525 polymorphism, a G to A substitution at position -238 in the promoter region of the gene, was observed with greater frequency in subjects with a chronic bronchitis phenotype [8]. Analysis of spontaneous sputum samples from 10 subjects revealed 100 times greater soluble TNF- $\alpha$ concentration compared to matched controls, suggesting the polymorphism may affect gene transcription. In addition, in lung secretions there was a higher concentration of downstream pro-inflammatory mediators, greater decline in lung function and lower BMI, indicating a more aggressive disease phenotype. No difference in serum concentration of TNF- $\alpha$ was observed and was low in both groups which may reflect rapid binding to tissue receptors preventing its detection [9].

Alpha-1 antitrypsin is involved in the modulation of TNF- $\alpha$ biosynthesis and AATD patients are known to have increased activation of the TNF- $\alpha$ pathway [10]. Therefore patients with both AATD and a proinflammatory TNF- $\alpha$ SNP might be more exposed to TNF- $\alpha$ inflammation, enhancing the cellular and clinical effects of the polymorphism.

We hypothesised that monocytes (a principal TNF- $\alpha$ producing cell) from subjects with AATD and COPD would produce more TNF- $\alpha$ if they carried the rs361525 polymorphism and that this would have an enhancing downstream effect on other monocyte functions relevant to COPD, such as phagocytosis and cytokine production. As no previous experiments had been conducted in monocytes with the rs361525 polymorphism from this patient group, it was not possible to power the current studies and hence the work presented here should be considered as a pilot study.

\section{Methods}

This study was conducted following ethical approval from the National Research Ethics Service Committee West Midlands, UK (reference number LREC-3359/ 3359-A). Patients with AATD and COPD were recruited from the UK AATD registry, held in Birmingham, UK, following the provision of written informed consent. All patients were clinically stable and exacerbation free for at least six weeks prior to recruitment. Patients were selected following careful matching for clinical criteria (described in Table 1). Subjects with the polymorphism are referred to as AG and those with the wildtype allele, GG. Monocytes were extracted using the Dynabeads ${ }^{\odot}$ Untouched $^{\mathrm{TM}}$ Human Monocytes kit (Life Technologies, Paisley, UK). Cells were re-suspended in culture medium (sterile Roswell Park Memorial Institute medium 1640 (Sigma Chemicals Ltd, Poole, UK) supplemented with $10 \%$ fetal calf serum, $10 \% \mathrm{~L}$-glutamine and $10 \%$ penicillinV and streptomycin and cultured at $37{ }^{\circ} \mathrm{C}$ and in $5 \%$ $\mathrm{CO}_{2}$. Monocytes were plated at a concentration of 0.25 (for mRNA experiments) or 0.45 million per $\mathrm{ml}$ (in duplicate for ELISA experiments) of culture medium. Salmonella Enteritidis derived lipopolysaccharide (LPS) (100 ng/ml; Sigma Chemicals Limited, Poole, UK) was chosen as the TNF- $\alpha$ stimulant after conducting concentration-response and time-course experiments in healthy control monocytes to confirm it elicited the greater response, compared to a number of other stimuli, with a peak time point for TNF- $\alpha$ protein $(6 \mathrm{~h}$ post LPS). An enzyme-linked immunosorbant assay (ELISA) was used to measure TNF- $\alpha$ in the cell-free supernatant according to manufacturer instructions (R\&D Systems, Abingdon, UK). The plates were read using a Synergy HT microplate reader (Biotech, GMI, Ramsey, USA). All samples and standards were run in duplicate. mRNA was extracted from each cell pellet using the Isolate RNA Minikit (Bioline, London, UK). Median 260/280 ratio of RNA samples was 2.1 (IQR 1.8-2.6). RNA samples were reverse transcribed using a High Capacity RNA-to-cDNA Kit (Life Technologies, Paisley, UK) in a Takara Thermal Cycler PCR machine (Takara Bioeurope, Saint-Germain-en-Laye, France). Real-time quantitative polymerase chain reaction (PCR) was carried out to quantify the expression of each gene of interest. Complementary deoxyribonucleic acid (cDNA) was mixed with Light Cycler 480 Probe PCR Master master mix (Roche Applied Science, Burgess Hill, UK), PCR-grade 
Table 1 Characteristics of study subjects

\begin{tabular}{|c|c|c|c|c|}
\hline \multicolumn{2}{|l|}{ Characteristic } & rs361525 + ve (AG/AA) & rs361525 -ve (GG) & $P$ value (2- tailed) \\
\hline \multirow{2}{*}{\multicolumn{2}{|c|}{$\mathrm{N}$}} & 9 & 9 & \\
\hline & & $(8 \mathrm{AG} / 1 \mathrm{AA})$ & & \\
\hline \multicolumn{2}{|c|}{ Presence of COPD } & $9 / 9$ & $9 / 9$ & \\
\hline \multicolumn{2}{|l|}{ Age in years } & $51(50-65)$ & $60(49-61)$ & 0.8 \\
\hline \multicolumn{2}{|l|}{ Male } & $7(77.8)$ & $7(77.8)$ & \\
\hline \multicolumn{2}{|c|}{ AATD level (micromolar) } & $3.8(0.4)$ & $4.0(0.5)$ & 0.8 \\
\hline \multicolumn{2}{|l|}{ BMI } & $21.2(21.0-23.8)$ & $23.2(22.0-26.0)$ & 0.3 \\
\hline \multirow[t]{2}{*}{ Smoking hx } & Current & 1 & 0 & \\
\hline & Ex/never & $7 / 1$ & $8 / 1$ & \\
\hline \multicolumn{2}{|l|}{ Pack years } & $22(10-28)$ & $22(9-30)$ & 0.9 \\
\hline \multicolumn{2}{|l|}{ FEV1 (L) } & $1.4(0.1)$ & $1.4(0.2)$ & 0.8 \\
\hline \multicolumn{2}{|c|}{ FEV1 \% predicted } & $37.7(33.4-43.4)$ & $33.6(32.6-54.6)$ & 0.9 \\
\hline \multicolumn{2}{|c|}{ FEV1/FVC ratio (\%) } & $32.0(28.0-34.0)$ & $32.2(23.0-33.0)$ & 0.5 \\
\hline \multicolumn{2}{|c|}{ KCO \% predicted } & $53.9(4.6)$ & $52.0(4.8)$ & 0.8 \\
\hline \multicolumn{2}{|c|}{ Emphysema on HRCT } & $8 / 9$ & $9 / 9$ & \\
\hline \multicolumn{2}{|c|}{ Chronic bronchitis phenotype } & $4 / 9$ & $5 / 9$ & \\
\hline \multicolumn{2}{|c|}{ Bronchiectasis on HRCT } & $4 / 9$ & $5 / 9$ & \\
\hline \multicolumn{2}{|c|}{ Inhaled steroids } & $8 / 9$ & $9 / 9$ & \\
\hline \multicolumn{2}{|c|}{ Median exacerbations per year } & $1.0(1.0-2.0)$ & $0.5(0-1.0)$ & 0.3 \\
\hline
\end{tabular}

The table shows key characteristics of subjects with (AG/AA) and without (GG) the rs361525 TNF-a polymorphism. Subjects were matched as closely as possible. Data is given as mean (SE) where normally distributed and median (IQR) where not normally distributed. An independent t-test was used to detect any difference between groups for the former data and a Mann Whitney $U$ test for the latter

water and the relevant fluorescein isothiocyanate-labelled TaqMan gene expression assay (Life Technologies, Paisley, UK), in each well of the plate. The reaction was run on a Roche Lightcycler 480 (Roche Applied Science, Burgess Hill, UK), for 45 amplification cycles. The Assay-onDemand numbers for the TaqMan assays were: glyceraldehyde 3-phosphate dehydrogenase (GAPDH): Hs99999905_m1; TNF- $\alpha$ : Hs00174128_m1. Where an individual normalising gene can be shown to be stably expressed in the model under study it is deemed acceptable to use only that one [11]. Stable reference genes have been classified as those in which the average fold change from the mean expression was less than 2 and the maximum variability in fold change less than 5 [12]. GAPDH was found to be stably expressed in a random selection of 64 samples (from different subjects and under a variety of experimental conditions) with a mean fold change from the mean CT value of 1.7 and a maximum fold change of 4.6. Singleplex reactions with equal starting quantities of cDNA were conducted. Samples were run in duplicate and the average of two cycle threshold values taken. The $2^{-\Delta C T}$ formula was used to calculate the relative expression of mRNA [13]. Data is presented as median and IQR and differences between groups tested with a Mann Whitney U test. Data was analysed using the SPSS statistical program (version 20.0 Chicago, USA).

\section{Results}

Table 1 shows the characteristics of study subjects. There were 9 subjects in each group. Data for mRNA work was available for only 8 subjects in each group (due to a technical issue in mRNA extraction for one subject). Patients were matched closely, as shown in Table 1 . There were no statistically significant differences between the groups.

Expression of TNF- $\alpha$ mRNA in freshly isolated unstimulated monocytes was low and there was no difference between AG and GG subjects (Fig. 1). No difference in mRNA expression or secreted protein was observed between the two groups in monocytes cultured without any stimulus (Fig. 2a and b). LPS-stimulated monocytes isolated from AG patients did not show more mRNA expression or protein concentration compared to the GG (wild type) (Fig. 2c and d). We hypothesized that measuring TNF- $\alpha$ on one occasion may be insufficient to determine a true difference between groups, should intra-subject variation in TNF- $\alpha$ secretion over time be high. Monocytes from 3 healthy subjects were therefore isolated twice weekly (3-4 days apart) for 3 weeks, stimulated with $100 \mathrm{ng} / \mathrm{ml}$ of LPS, and TNF- $\alpha$ concentration in the cell-free supernatant measured at $3 \mathrm{~h}$. Figure 3 shows the values over 3 weeks for each subject. Coefficient of variation percentage values for subjects 


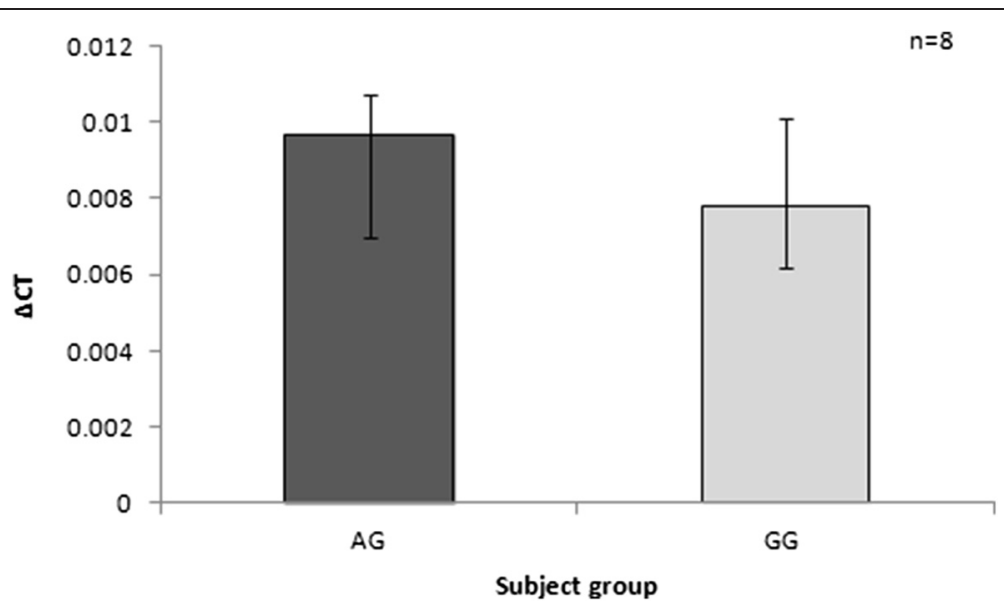

Fig. 1 Baseline expression of TNF-a mRNA in freshly isolated monocytes from patients with and without the rs361525 TNF-a polymorphism. Columns show median (IQR) $\triangle C T$ values for TNF-a mRNA expression (normalised to GAPDH). Differences between subject groups were assessed with a Mann Whitney $U$ test. There was no significant increase in TNF-a mRNA expression in the AG monocytes

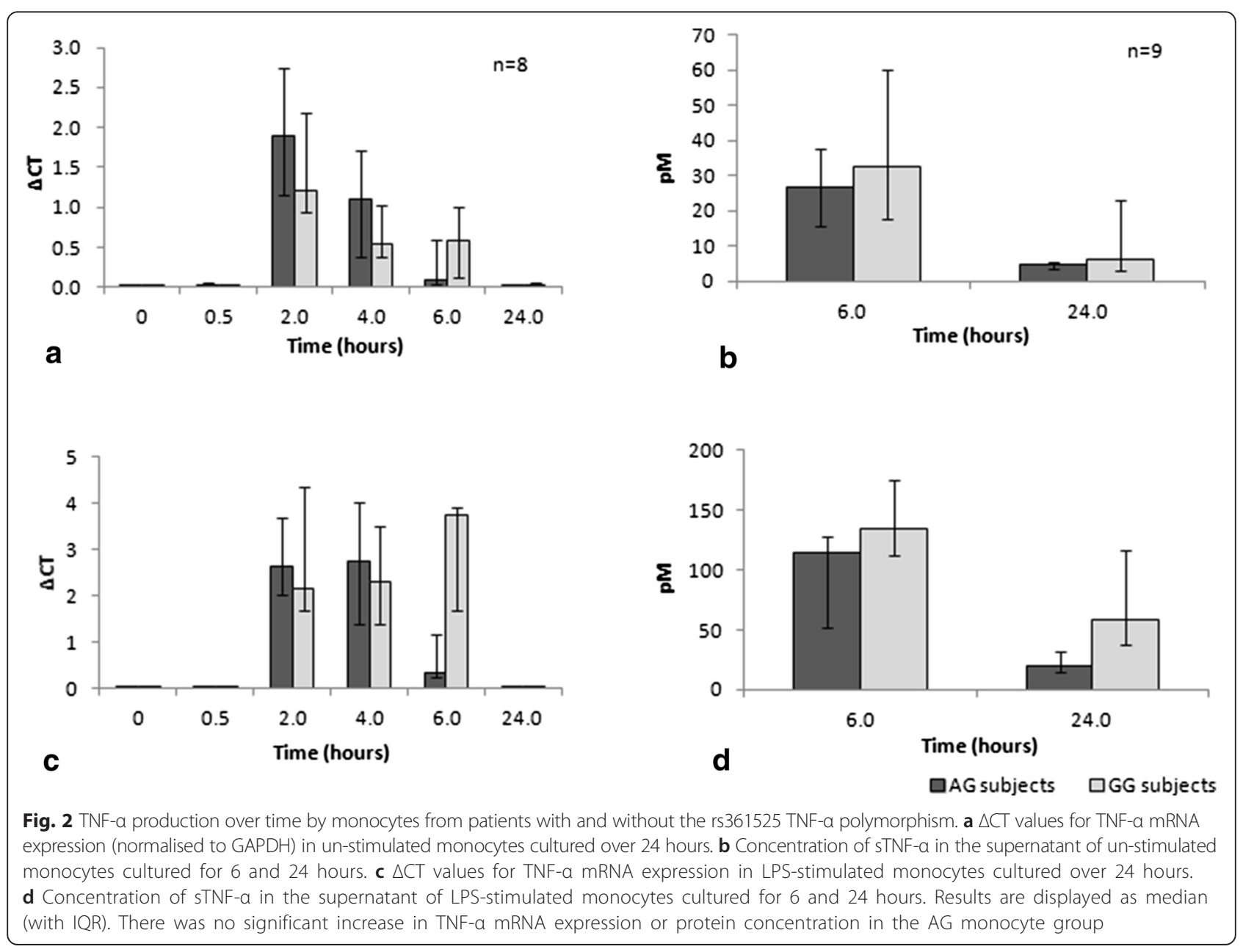




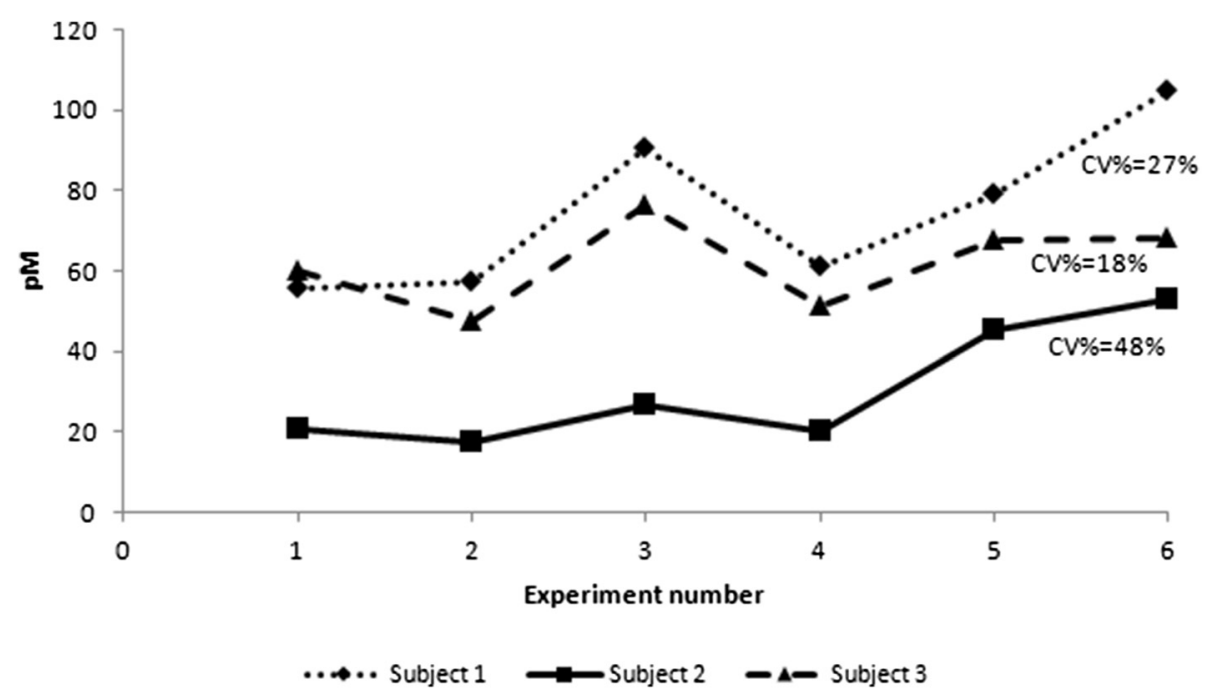

Fig. 3 TNF-a secretion by LPS-stimulated monocytes over three weeks. Monocytes from 3 healthy subjects (2 female) were isolated twice weekly for 3 weeks and stimulated in duplicate with $100 \mathrm{ng} / \mathrm{ml}$ of LPS for 3 hours. TNF-a concentration in the cell-free supernatant was measured using ELISA. Coefficient of variation (CV\%) values for each subject are shown

one to three were $26.9,48.4$ and $17.7 \%$. These data were used to calculate that a sample size of 40 patients per AG/GG group would be required to demonstrate a true $20 \%$ difference in sTNF- $\alpha$ concentration in the supernatants six hours post LPS stimulation with approximately $80 \%$ power.

\section{Discussion}

The pilot studies presented here did not support the findings in the sputum of COPD/AATD patients with the rs361525 polymorphism, which was surprising given the magnitude of difference observed in the airways [9]. It is clear from subsequent experiments studying the intra-subject variation in TNF- $\alpha$ that large numbers of subjects in each group would be required to have adequate power to detect even a modest difference in production should this exist in monocytes in relation to this stimulus and hence further studies were not conducted.

There are other possible explanations for the lack of expected effect. Although LPS has been shown to induce transcription of TNF- $\alpha$ mRNA in immortalised cells of the monocyte lineage with the AG genotype using a reporter gene assay [14], the same study demonstrated that multiple hits are required to maximally potentiate the effects of the polymorphism. Specifically, binding of thyroid hormone receptor to the A allele in addition to LPS-induced nuclear factor kappa beta was necessary. It is possible that the complex cytokine milieu in the lungs of COPD patients is such that multiple mechanisms are in place to enhance TNF- $\alpha$ mRNA transcription in subjects with the A allele. By the same rationale it may be that the effects of the polymorphism are specific to the airways of COPD/AATD patients with chronic bronchitis, due to specific local stimulating factors, again potentially reducing the power if this is the critical disease phenotype. In the current study only $50 \%$ of subjects had chronic bronchitis in addition to emphysema, and these low numbers prevented further analysis of any clinical subgroup. Finally, monocytes may not be the relevant cell to study. The increased TNF- $\alpha$ concentration in the sputum might reflect output specifically from macrophages, T-cells or bronchial epithelial cells. Indeed, the original study found no difference in systemic levels of TNFa between groups perhaps suggesting this is a compartment specific finding [9].

In summary our findings did not support our primary hypothesis but are consistent with the literature describing the effects of this particular polymorphism. Studies report positive, negative and no effects, in a range of cells types, employing a wide variety of techniques to measure output and in different disease states $[9,14-25]$. This study reflects the inherent difficulty in studying the effects of SNPs at a cellular level and we suggest further investigation of the rs361525 SNP should focus on airway derived cells and local transcription factors.

\section{Abbreviations}

AATD: Alpha-1 Antitrypsin Deficiency; BMI: Body mass index; CDNA: Complementary deoxyribonucleic acid; COPD: Chronic obstructive pulmonary disease; CV\%: Coefficient of variation percentage; ELISA: Enzyme-linked immunosorbant assay; FEV1: Forced expiratory volume in 1 second; FVC: Forced vital capacity; GAPD: Glyceraldehyde 3-phosphate dehydrogenase; HRCT: High resolution computed tomography; KCO: Transfer coefficient; LPS: Lipopolysaccharide; mRNA: Messenger ribonucleic acid; PCR: Polymerase chain reaction; SNP: Single nucleotide polymorphism; TNF-a: Tumour necrosis factor-alpha. 


\section{Competing interests}

The authors declare that they have no conflict of interest.

\section{Authors' contributions}

JG designed studies, carried out and analyzed the results of all assays and wrote the manuscript. ES and RS designed the study, contributed to interpretation of results and contributed to the manuscript. All authors read and approved the final manuscript.

\section{Acknowledgments}

We thank Dr Gillian McNab for laboratory assistance and Dr Peter Nightingale for assistance with statistical power calculations. Funding was provided by the West Midlands Chest Fund. Clinical studies were supported by the Birmingham Health Partners NIHR/Wellcome Clinical Research Facility.

\section{Author details}

${ }^{1}$ Institute of Inflammation and Ageing, University of Birmingham, Edgbaston, Birmingham B15 2TT, UK. ${ }^{2}$ Lung Investigation Unit, University Hospital Birmingham NHS Foundation Trust, Edgbaston, Birmingham, UK. ${ }^{3}$ Centre for Translational Inflammation Research, New Queen Elizabeth Hospital, University of Birmingham Laboratories, Institute of Inflammation and Ageing, Edgbaston, Birmingham B15 2TT, UK.

\section{Received: 20 August 2015 Accepted: 16 November 2015}

\section{Published online: 01 December 2015}

\section{References}

1. Lokke A, Lange P, Scharling H, Fabricius P, Vestbo J. Developing COPD: a 25 year follow up study of the general population. Thorax. 2006;61(11):935-39.

2. Wood AM, Stockley RA. Alpha one antitrypsin deficiency: from gene to treatment. Respiration. 2007;74(5):481-92.

3. Churg A, Wang RD, Tai H, Wang X, Xie C, Wright JL. Tumor necrosis factor-alpha drives $70 \%$ of cigarette smoke-induced emphysema in the mouse. Am J Respir Crit Care Med. 2004;170(5):492-98.

4. Churg A, Dai J, Tai H, Xie C, Wright JL. Tumor necrosis factor-alpha is central to acute cigarette smoke-induced inflammation and connective tissue breakdown. Am J Respir Crit Care Med. 2002;166(6):849-54

5. Sapey E, Bayley D, Ahmad A, Newbold P, Snell N, Stockley RA. Inter-relationships between inflammatory markers in patients with stable COPD with bronchitis: intra-patient and inter-patient variability. Thorax. 2008;63(6):493-99.

6. Sapey E, Ahmad A, Bayley D, Newbold P, Snell N, Rugman P, et al. Imbalances between interleukin-1 and tumor necrosis factor agonists and antagonists in stable COPD. J Clin Immunol. 2009;29(4):508-16.

7. Rennard SI, Fogarty C, Kelsen S, Long W, Ramsdell J, Allison J, et al. The safety and efficacy of infliximab in moderate to severe chronic obstructive pulmonary disease. Am J Respir Crit Care Med. 2007;175(9):926-34.

8. Wood AM, Simmonds MJ, Bayley DL, Newby PR, Gough SC, Stockley RA. The TNFalpha gene relates to clinical phenotype in alpha-1-antitrypsin deficiency. Respir Res. 2008;9:52.

9. Sapey E, Wood AM, Ahmad A, Stockley RA. Tumor necrosis factor-alpha rs361525 polymorphism is associated with increased local production and downstream inflammation in chronic obstructive pulmonary disease. Am J Respir Crit Care Med. 2010;182(2):192-99.

10. Bergin DA, Reeves EP, Hurley K, Wolfe R, Jameel R, Fitzgerald S, et al. The circulating proteinase inhibitor $a-1$ antitrypsin regulates neutrophil degranulation and autoimmunity. Sci Transl Med. 2014;6(217):217ra1.

11. Huggett J, Dheda K, Bustin S, Zumla A. Real-time RT-PCR normalisation; strategies and considerations. Genes Immun. 2005;6:279-84.

12. Dheda K, Huggett JF, Bustin SA, Johnson MA, Rook G, Zumla A. Validation of housekeeping genes for normalizing RNA expression in real-time PCR. Biotechniques. 2004;37(1):112-19.

13. Wong ML, Medrano JF. Real-time PCR for mRNA quantitation. Biotechniques. 2005;39(1):75-85.

14. Kiss-Toth E, Harlock E, Lath D, Quertermous T, Wilkinson JM. A TNF variant that associates with susceptibility to musculoskeletal disease modulates thyroid hormone receptor binding to control promoter activation. PLoS One. 2013;8(9):e76034.

15. Mekinian A, Tamouza R, Pavy S, Gestermann N, Ittah M, Mariette X, et al. Functional study of TNF-alpha promoter polymorphisms: literature review and meta-analysis. Eur Cytokine Netw. 2011;22(2):88-102.
16. Kaijzel EL, van Krugten MV, Brinkman BM, Huizinga TW, van der Straaten T, Hazes JM, et al. Functional analysis of a human tumor necrosis factor alpha (TNF-alpha) promoter polymorphism related to joint damage in rheumatoid arthritis. Mol Med. 1998;4(11):724-33.

17. Uglialoro AM, Turbay D, Pesavento PA, Delgado JC, McKenzie FE, Gribben JG, et al. Identification of three new single nucleotide polymorphisms in the human tumor necrosis factor-alpha gene promoter. Tissue Antigens. 1998;52(4):359-67.

18. Pissetti CW, Correia D, de Oliveira RF, Llaguno MM, Balarin MA, Silva-Grecco $\mathrm{RL}$, et al. Genetic and functional role of TNF-alpha in the development Trypanosoma cruzi infection. PLoS Negl Trop Dis. 2011;5(3)

19. Kaluza W, Reuss E, Grossmann S, Hug R, Schopf RE, Galle PR, et al. Different transcriptional activity and in vitro TNF-alpha production in psoriasis patients carrying the TNF-alpha 238A promoter polymorphism. J Invest Dermatol. 2000;114(6):1180-83.

20. Westendorp RG, Langermans JA, Huizinga TW, Verweij CL, Sturk A. Genetic influence on cytokine production in meningococcal disease. Lancet. 1997;349(9069):1912-13.

21. Pociot F, D'Alfonso S, Compasso S, Scorza R, Richiardi PM. Functional analysis of a new polymorphism in the human TNF alpha gene promoter. Scand J Immunol. 1995;42(4):501-04.

22. Haddy N, Sass C, Maumus S, Marie B, Droesch S, Siest G, et al. Biological variations, genetic polymorphisms and familial resemblance of TNF-alpha and IL-6 concentrations: STANISLAS cohort. Eur J Hum Genet. 2005;13(1):109-17.

23. Oregon-Romero E, Vazquez-Del Mercado M, Ruiz-Quezada SL, Navarro-Hernandez RE, Rangel-Villalobos H, Martinez-Bonilla G, et al. Tumor necrosis factor alpha-308 and -238 polymorphisms in rheumatoid arthritis. Association with messenger RNA expression and sTNF-alpha. J Investig Med. 2008;56(7):937-43.

24. Huizinga TW, Westendorp RG, Bollen EL, Keijsers V, Brinkman BM, Langermans JA, et al. TNF-alpha promoter polymorphisms, production and susceptibility to multiple sclerosis in different groups of patients. J Neuroimmunol. 1997;72(2):149-53.

25. O'Dwyer MJ, Mankan AK, Ryan AW, Lawless MW, Stordeur P, Kelleher $D$, et al. Characterization of tumour necrosis factor-alpha genetic variants and mRNA expression in patients with severe sepsis. Int J Immunogenet. 2008;35(4-5):279-85.

\section{Submit your next manuscript to BioMed Central and we will help you at every step: \\ - We accept pre-submission inquiries \\ - Our selector tool helps you to find the most relevant journal \\ - We provide round the clock customer support \\ - Convenient online submission \\ - Thorough peer review \\ - Inclusion in PubMed and all major indexing services \\ - Maximum visibility for your research}

Submit your manuscript at www.biomedcentral.com/submit 